\title{
Enhancing geological and hydrogeological understanding of the Precipice Sandstone aquifer of the Surat Basin, Great Artesian Basin, Australia, through model inversion of managed aquifer recharge datasets
}

\author{
Phil Hayes $^{1}$ (D) - Chris Nicol ${ }^{2}$ - Andrew D. La Croix ${ }^{3}$ • Julie Pearce ${ }^{1,4}$ - Sebastian Gonzalez ${ }^{1}$. Jiahao Wang ${ }^{5}$. \\ Ahmed Harfoush ${ }^{1} \cdot$ Jianhua He $^{6}$. Andrew Moser ${ }^{7} \cdot$ Lauren Helm $^{7} \cdot$ Ryan Morris $^{8}$ - David Gornall ${ }^{9}$
}

Received: 5 April 2019 / Accepted: 3 November 2019 / Published online: 24 December 2019

(C) The Author(s) 2019

\begin{abstract}
The Precipice Sandstone is a major Great Artesian Basin aquifer in the Surat Basin, Queensland, Australia, which is used for water supply and production of oil and gas. This report describes use of observed groundwater pressure responses to managed aquifer recharge (MAR) at a regional scale to test recent geological descriptions of Precipice Sandstone extent, and to inform its hydrogeological conceptualisation. Since 2015, two MAR schemes have injected over 20 GL of treated water from coal seam gas production into the Precipice Sandstone, with pressure responses rapidly propagating over $100 \mathrm{~km}$, indicating high aquifer diffusivity. Groundwater modelling of injection and inversion of pressure signals using PEST software shows the spatial variability of aquifer properties, and indicates that basin in-situ stresses and faulting exert control on permeability. Extremely high permeability, up to $200 \mathrm{~m}$ /day, occurs in heavily fractured regions with a dual-porosity flow regime. The broader-scale estimates of permeability approach an order of magnitude higher than previous studies, which has implications for the management of water resources in the Precipice Sandstone. Results also show the Precipice Sandstone to have broadly isotropic permeability. The results also support a recent geological interpretation of the Precipice Sandstone as having more limited lateral extent than initially considered. The study shows the effective use of MAR injection data to improve geological and hydrogeological understanding through groundwater model inversion. It also demonstrates the utility of combining hydrogeological and reservoir-engineer datasets in areas explored and developed for both groundwater resources and oil and gas resources.
\end{abstract}

Keywords Managed aquifer recharge $\cdot$ Australia $\cdot$ Inverse modelling $\cdot$ Hydraulic properties $\cdot$ Oil and gas

Published in the special issue "Advances in hydrogeologic understanding of Australia's Great Artesian Basin"

Electronic supplementary material The online version of this article (https://doi.org/10.1007/s10040-019-02079-9) contains supplementary material, which is available to authorized users.

Phil Hayes

Phil.hayes@uq.edu.au

1 Centre for Natural Gas, University of Queensland, Brisbane 4072, Australia

2 Groundwater Logic, Melbourne, Australia

3 School of Science, University of Waikato, Hamilton 3240, New Zealand

4 School of Earth and Environmental Science, University of Queensland, Brisbane 4072, Australia
5 Key Laboratory of Petroleum Resources, China University of Geosciences, Wuhan 430074, China

6 Key Laboratory of Marine Reservoir Evolution and Hydrocarbon Enrichment Mechanisms, China University of Geosciences, Beijing 100083, China

Origin/APLNG, Brisbane, Australia

RDM Hydro, Brisbane, Australia

9 Santos/GLNG, Brisbane, Australia 


\section{Introduction}

Hydrogeological understanding of the Great Artesian Basin's (GAB) Surat Basin (Queensland, Australia) has progressed over the last 8 years due to the rapid development of coal seam gas (CSG, known elsewhere as coal bed methane) industry, which extracts groundwater from the Walloon Coal Measures coal seams to produce gas. Regulation of the CSG industry by the Queensland Government has included declaration of a cumulative management area (CMA) (Fig. 1), within which overlapping impacts from multiple CSG projects are assessed by the Office for Groundwater Impact Assessment (OGIA). OGIA completes hydrogeological and modelling studies to predict regional impacts of petroleum production on groundwater resources.

The extraction of CSG requires reduction of pressure in the coal seams to release gas. The pressure reduction is achieved by extracting groundwater, and this associated water requires management by the CSG industry. Environmental permitting by the Queensland Government (EHP 2012) promotes the beneficial reuse of the water rather than disposal via methods such as enhanced evaporation. Much of the CSG water is reused for irrigation, typically after some treatment such as reverse osmosis, to decrease the total dissolved solids (Towler et al. 2016). Another use of the water is the artificial recharge of the Precipice Sandstone by two Managed Aquifer Recharge (MAR) schemes.

The Surat Basin covers approximately $\sim 327,000 \mathrm{~km}^{2}$ of south-eastern Queensland and northern New South Wales in eastern Australia, stretching from 25 to $33^{\circ} \mathrm{S}$ and from 147 to $152^{\circ} \mathrm{E}$ (Fig. 1). The Surat Basin contains a sequence of Jurassic and Cretaceous sediments and hosts regional-scale aquifers and aquitards with a total thickness that exceeds 2,500 $\mathrm{m}$. The Surat overlies the older Permo-Triassic Bowen Basin sequence that contains source rocks for thermogenic oil and gas accumulations within the Precipice Sandstone (Underschultz et al. 2016). A key challenge for regulators and water resource management in the Surat Basin is hydrogeological conceptualisation, particularly of more deeply confined aquifers. Despite recent advances in
Fig. 1 Location of Surat Basin within the Great Artesian Basin of Australia, and the Surat Cumulative Management Area (CMA)

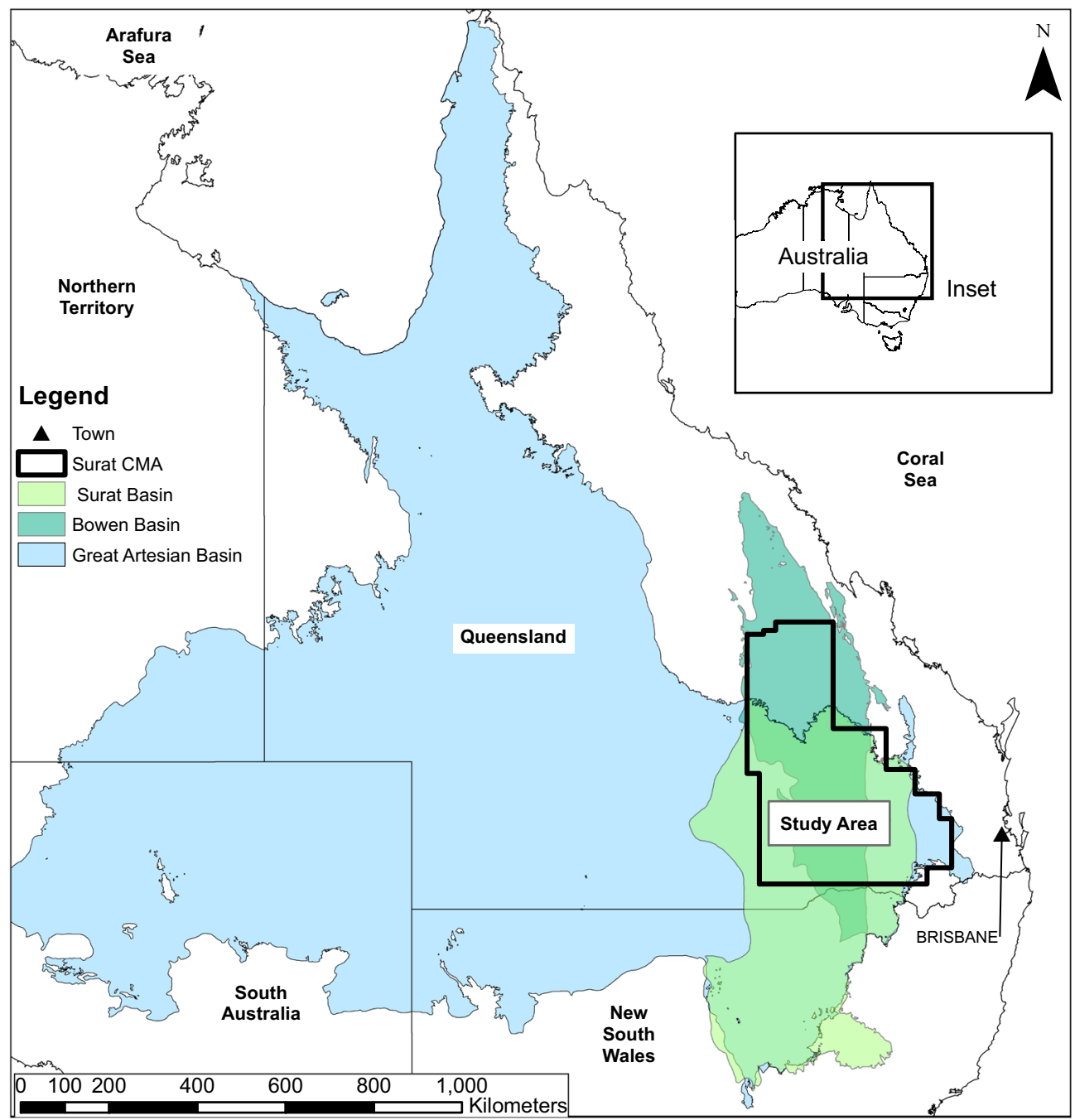


hydrogeological understanding of the basin, fundamental questions regarding flow pathways, mechanisms for groundwater discharge and the regional-scale properties of some units remain. Answering these questions is critical for the long-term sustainable management of groundwater resources.

The Surat Basin has overlapping land uses including grazing and arable agriculture, forestry, mining and conventional and unconventional oil and gas (Ransley et al. 2015). Agricultural expansion to the west of the Great Dividing Range into southern and central Queensland grew rapidly from the late nineteenth century with the discovery of $\mathrm{GAB}$ artesian groundwater and the drilling of deep bores (Akers 2010). Within the Surat CMA, an area larger than the Surat Basin, there are now approximately 23,000 groundwater bores, extracting an estimated 197-207 GL/year of water (Keir et al. 2017, 2019; OGIA 2016a). Groundwater use is primarily for agricultural irrigation and for stock and domestic water demand, with smaller volumes used for town water and industrial supplies.

The Jurassic-age Precipice Sandstone is the basal unit of the Surat Basin, which is both a regionally extensive major GAB aquifer with typically low-salinity groundwater, and a productive oil and gas reservoir. Water abstraction from the Precipice Sandstone for town water, stock and domestic and industrial use is estimated to be between 4 and $13 \mathrm{GL} /$ year from approximately 800 water bores (Keir et al. 2019). The Precipice Sandstone is also being artificially recharged by two MAR schemes operated by Origin Energy, on behalf of Australia Pacific LNG (APLNG). This water, extracted from the Walloon Coal Measures, is a by-product of CSG production and undergoes filtration and treatment prior to injection into the Precipice Sandstone. The Precipice Sandstone has also had conventional oil and gas extraction since the 1960s (O'Sullivan et al. 1991) with variable rates of production (Towler et al. 2016). Petroleum related exploration seismic and drilling have assisted development of geological and stratigraphical understanding of the basin. By mid-2018 over 5000 unconventional CSG wells were operating in the Surat Basin (Queensland Government 2018) extracting gas from the Walloon Coal Measures. Besides gas, these wells also produced $48 \mathrm{GL} /$ year of associated groundwater (Queensland Government 2018), at an average rate of $26 \mathrm{~m}^{3} /$ day per CSG well. More recently, the Surat Basin and Precipice Sandstone have been identified as potential hosts for carbon capture and storage (CCS) for sequestration of supercritical Carbon Dioxide (Bradshaw et al. 2002; Allinson et al. 2003; Bradshaw et al. 2011; Hodgkinson and Grigorescu 2013).

The exploration and development of the Surat Basin for both groundwater, and oil and gas resources, and more latterly the focus brought by CSG production and evaluation for CCS presents a unique opportunity to combine data sources from petroleum engineering and hydrogeology. The observed response in the Precipice Sandstone to the MAR schemes provides a dataset akin to a long-term pumping test through the northern Surat Basin and represents a rare opportunity to test recently developed geological concepts of the Precipice Sandstone and to inform its hydrogeological conceptualisation at a regional scale. By inverting pressure responses using a groundwater model the permeability and connectivity across a large portion of a GAB basin can be investigated and the role of structure and stress at a regional scale explored. The objectives of this are: (1) testing the geological conceptualisation, particularly the spatial extent of the permeable lower Precipice Sandstone unit; (2) characterisation of the hydraulic properties of the Precipice Sandstone and their spatial variability; and (3) informing the conceptualisation of the Precipice as a GAB aquifer and the factors that influence hydraulic properties and their spatial variability.

\section{Case study: the Precipice Sandstone}

\section{Geology}

The lowermost units in the Surat Basin are the Precipice Sandstone and Evergreen Formation. These comprise a major interval for water and hydrocarbons (the Precipice Sandstone), as well as a secondary reservoir and aquitard (the Evergreen Formation) that sits above it (Fig. 2). The Evergreen Formation shows a very complex arrangement of sandstones and mudstones that have been difficult to interpret especially in regard to fluid flow connectivity. Interpretations have evolved and a substantial body of literature is building in relation to the stratigraphic stacking patterns that characterize the Precipice Sandstone and Evergreen Formation as being mostly interpreted as nonmarine deposits that accumulated in an intracratonic setting (Sell et al. 1972; Martin 1980; Green et al. 1997). The Precipice Sandstone is generally agreed to represent high-energy braided river deposits because of its consistently thick coarse-grained cross-stratified sandstones with only thin interspersed mudstone intervals. The Evergreen Formation was previously considered as deposits of meandering rivers and freshwater lakes (Mollan et al. 1972; Exon 1976; Cosgrove and Mogg 1985). The most recent effort has been to update paleodepositional interpretations as sedimentological, ichnological, and palynological data has pointed towards substantial marine influence in the Surat during the early Jurassic (Bianchi et al. 2018; Martin et al. 2018; La Croix et al. 2019). This has important implications for the orientation, size, and connectivity of geobodies that comprise flow units.

The most comprehensive sequence stratigraphic analysis undertaken in the Surat Basin to date has challenged the notion that the Precipice Sandstone is as widespread as previously interpreted (Wang et al. 2019). In this scheme, strata are correlated as onlapping paleo-topographic highs in the sub- 


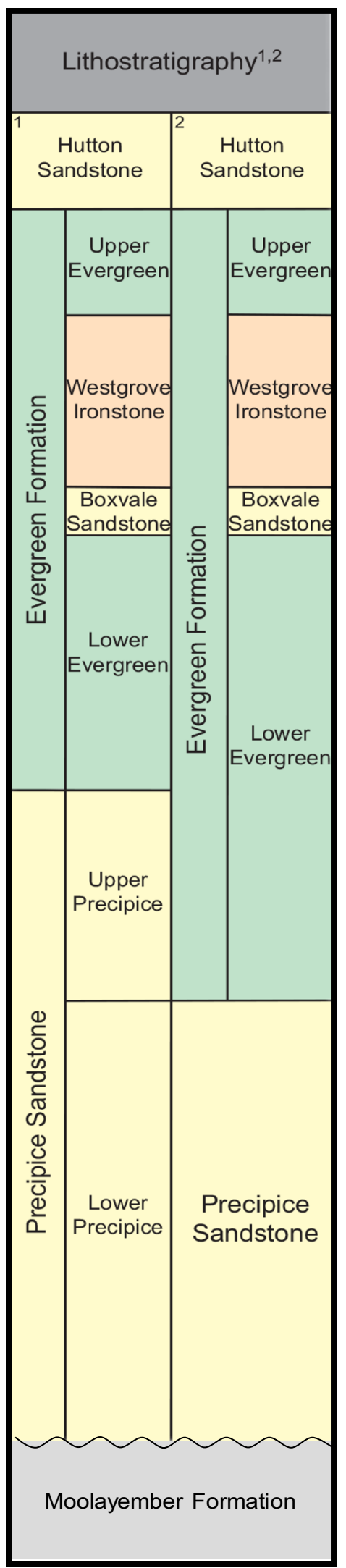

Fig. 2 Lithostratigraphic schemes for the Surat Jurassic System (1 after Exon et al. 1967; Gray 1968; Rigby and Kanstler 1987; Martin et al. 2018; 2 after Mollan et al. 1972; Green et al. 1997; Wang et al. 2019)
Surat unconformity and this significantly changes conceptualisation of the areal distribution of the main aquifer unit by decreasing its extent (Fig. 3).

Core and wireline log facies characterisation indicate that what was previously grouped into the "lower Precipice" and "upper Precipice" intervals (Fig. 2) by Martin et al. (2018) are really two very distinctive depositional intervals (La Croix et al. 2019). The lowermost unit comprises coarse-grained cross-bedded sandstone and the upper unit consists of fineto-medium-grained sandstones with cross bedding derived from wave and river flow processes with a retrogradational or back-stepping facies stacking pattern. Thus, the two units are distinct from one another, and Wang et al. (2019) suggests that this is sufficient reason not to group them. Sequence stratigraphy using logs and seismic also supports this subdivision of the Precipice-Evergreen succession as does mineralogical analysis (Grigorescu 2011; Bianchi et al. 2018; La Croix et al. 2019; Pearce et al. 2019). Precipice Sandstone drill core is generally up to $90-95 \%$ quartz, whereas the overlying Evergreen Formation is more mineralogically diverse with higher proportions of clays and feldspars - an example is the Geological Survey of Queensland Roma 8 well (Fig. 3b) with sandstones of quartz content $<70 \%$ more consistent with the Evergreen Formation.

In summary, several independent lines of evidence support the interpretation that the Precipice Sandstone is a distinctive depositional entity that has a more confined spatial distribution than previously considered. Sandstone bodies, which overlie the Precipice Sandstone, probably have a more limited lateral extent, greater clay content and correspondingly more limited hydraulic connectivity. These are the types of geobodies which occur up onto the Roma Shelf on the western side of the Surat Basin, from which conventional oil and gas has historically been produced. The recently revised geological interpretation concerning the areal extent of connected, high-quartz content, permeable sandstone is tested using the pressure observations of MAR injection and groundwater modelling.

\section{Precipice Sandstone hydrogeology and modelling}

The hydrogeology of the GAB and the Surat Basin, including the Precipice Sandstone aquifer, has been developed in detail (Hitchon and Hays 1971; Smerdon and Ransley 2012; OGIA 2016a). OGIA (2016a) provide the most detailed recent description of the geology and stratigraphy of the Surat Basin, and use that as a basis to develop a hydrogeological conceptual model that includes the distribution, thickness and properties of the aquifers and aquitards, their hydraulic parameter ranges, hydrochemistry, potentiometric surfaces and water tables, and a description of the hydrodynamics.

The Office for Groundwater Impact Assessment (OGIA 2016a) describes the outcrop of the Precipice Sandstone 

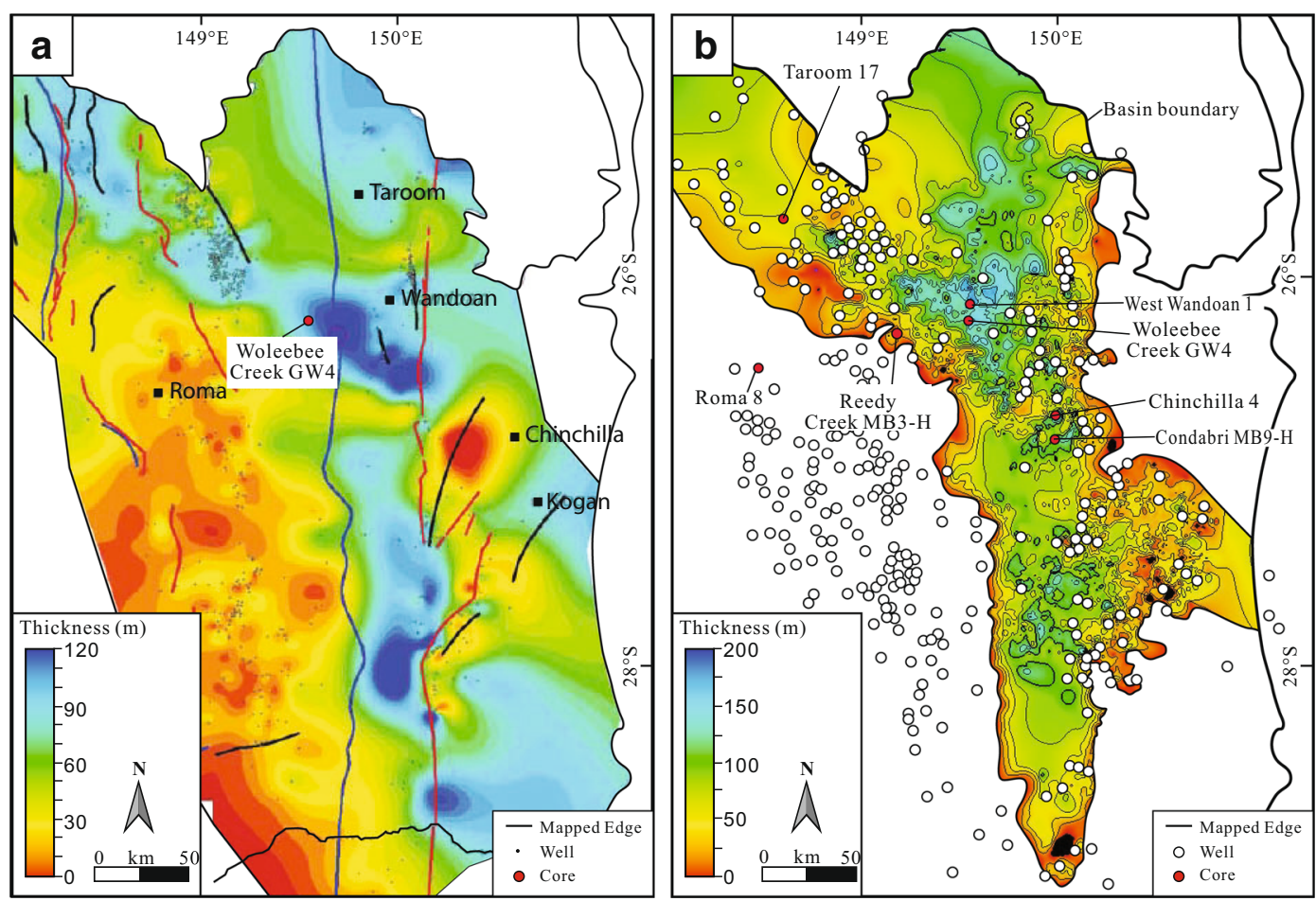

Fig. 3 Difference in the interpretation of how the 'Lower Precipice' Sandstone/Precipice Sandstone are mapped across the Surat Basin. Thickness of the aquifer shown in a map from Martin et al. 2018 and b from Wang et al. (2019)

defining the northern limit of the Surat Basin, and with an overall extent similar to that shown in Fig. 3a (Martin et al. 2018). OGIA (2016a) represents the Precipice Sandstone with thicknesses of up to $120 \mathrm{~m}$, thinning to $10-50 \mathrm{~m}$ across the Roma Shelf area (vicinity of 'Roma', Fig. 3a). The majority of the Precipice Sandstone is confined between the significant regional aquitards of the Evergreen and Moolayember formations, with a relatively small area of unconfined conditions close to outcrop. The Precipice Sandstone is also interpreted to have two limited areas of direct contact with the underlying Bandanna Formation coal measures of the Bowen Basin. From analysis of core, drill stem test (DST), petrophysical and pumping test data, OGIA (2016a) derived a range of permeability values for the Precipice Sandstone from 13 and 2,350 milliDarcy ( $\mathrm{mD}$; around $1.7 \mathrm{e}-02$ to $3.0 \mathrm{~m} /$ day), with porosities of $0.05-0.26$.

The Office for Groundwater Impact Assessment (OGIA 2016a) reports the chloride mass balance method providing an annual recharge rate to the Precipice Sandstone outcrop of $20.8 \mathrm{~mm} /$ year, approximately four times that estimated for other GAB aquifers. From outcrop, OGIA's (2016a) potentiometric surface maps indicate regional flow in the northern Surat from west to east, toward Taroom and the Dawson River. Further south flow appears orientated northeast to southwest with some depression of potentiometric levels that are thought related to abstraction. OGIA (2016a) describes significant discharges from the Precipice Sandstone into the Dawson River and springs adjacent to the river in the northern
Surat. Discharge mechanisms to the south are not discussed by OGIA (2016a), although connection is postulated by Smerdon and Ransley (2012) eastward across the 'Helidon Ridge' into the Clarence-Morton Basin. Precipice Sandstone groundwater is reported by OGIA (2016a) as being the freshest in the Surat Basin with mean total dissolved solids $<200 \mathrm{mg} / \mathrm{L}$, although this may be biased to records from the northern Surat.

Suckow et al. (2018) investigated the groundwater hydrochemistry of the northern Surat Basin including the Precipice Sandstone (see Fig. 4). They report estimated average flow velocities of $0.8-1.5 \mathrm{~m} /$ year over a transect of $\sim 170 \mathrm{~km}$, although noted some areas could be higher in preferential flow paths. Groundwater flow was reported to the north-east (Dawson River discharge), east and additionally to the south towards the deeper basin region. They report relatively higher total dissolved solids (TDS) and salinity to the east of the Leichhardt-Burunga fault zone (see Fig. 5) on the eastern side of the Surat and found hydrochemical evidence of connectivity up fault (water ascending) between the Precipice and Hutton Sandstone at the Hutton-Wallumbilla Fault zone and potentially the Leichhardt-Burunga fault zone.

OGIA's (2016a) hydrogeological conceptualisation was applied as the basis for development of a detailed groundwater model of the Surat CMA used to predict future impacts from CSG development as reported in the 2016 Underground Water Impact Report (OGIA 2016b) and a separate model report (OGIA 2016c). This model integrates significant time series of observed groundwater pressures and estimates of 
Fig. 4 Observed groundwater pressure responses to managed aquifer recharge (MAR) injection into the Precipice Sandstone

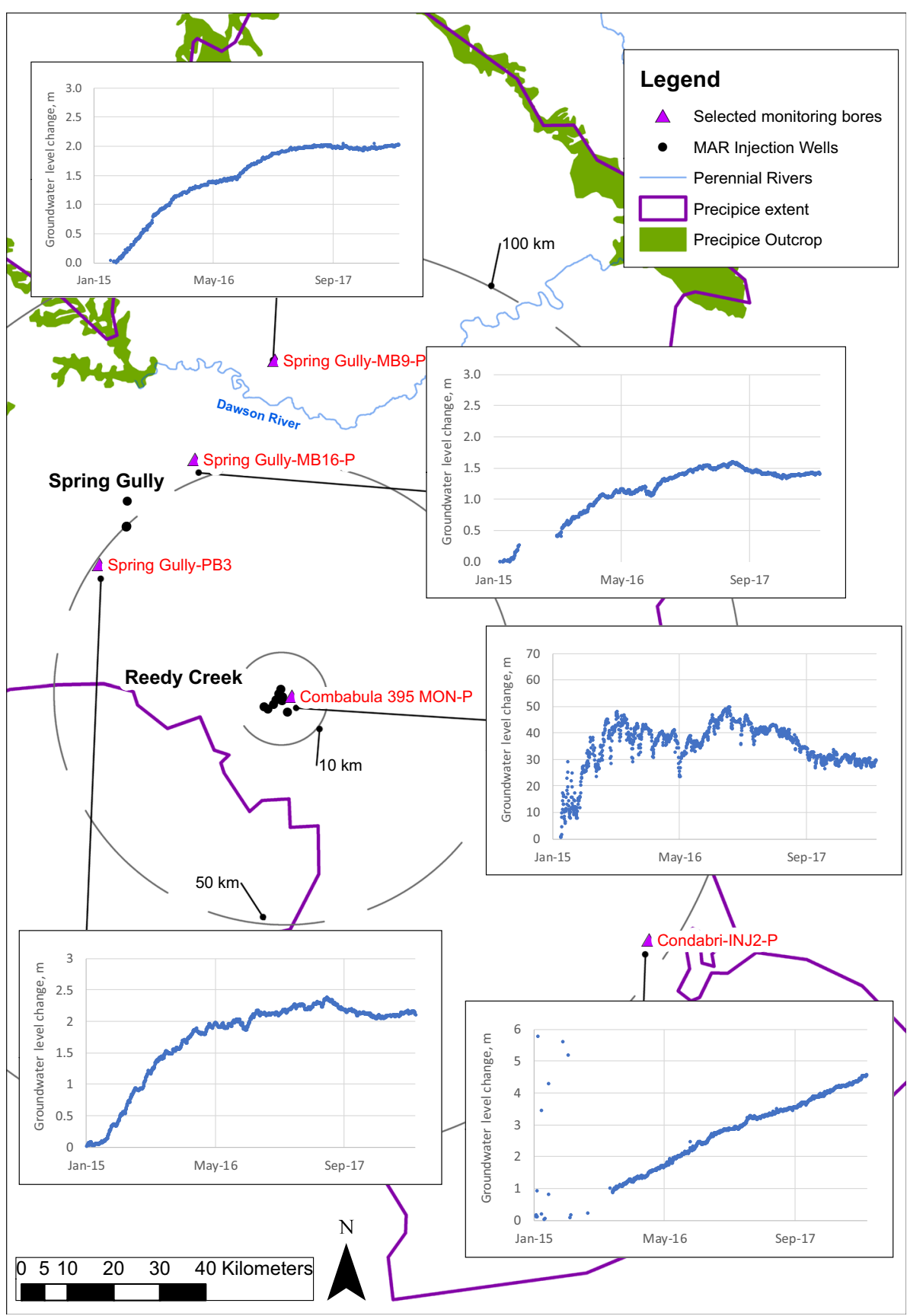

groundwater extraction with the PEST parameter-estimation software for calibration. However, the 2016 UWIR model predates full operation of the APLNG MAR schemes and therefore did not invert MAR observations.

\section{Precipice Sandstone managed aquifer recharge}

After exploration, testing and a number of trials, the APLNG project has opted to reuse CSG-associated water to enhance groundwater resources within the Precipice Sandstone aquifer via a MAR program (Origin Energy 2018) at some of its operations. MAR operates at two sites, Reedy Creek and
Spring Gully (Fig. 4). Both sites commenced injection early in 2015 and by June 2018 had injected over 20.5 GL of water. In addition, a short-term trial was undertaken at Condabri, near Miles (Fig. 5). The majority of injection has occurred at Reedy Creek (approximately $19 \mathrm{GL}$ ) at an initial average daily rate of $25 \mathrm{ML} /$ day, which has now declined to around $12 \mathrm{ML} /$ day (Origin Energy 2018). At Reedy Creek, MAR injection has increased groundwater heads by up to $50 \mathrm{~m}$ and a pressure signal has propagated through the Precipice Sandstone across much of the northern Surat. A report by APLNG indicates a piezometric head increase of $4 \mathrm{~m}$ at Miles, around $100 \mathrm{~km}$ from the injection site (Fig. 4). To the north of Reedy Creek, 


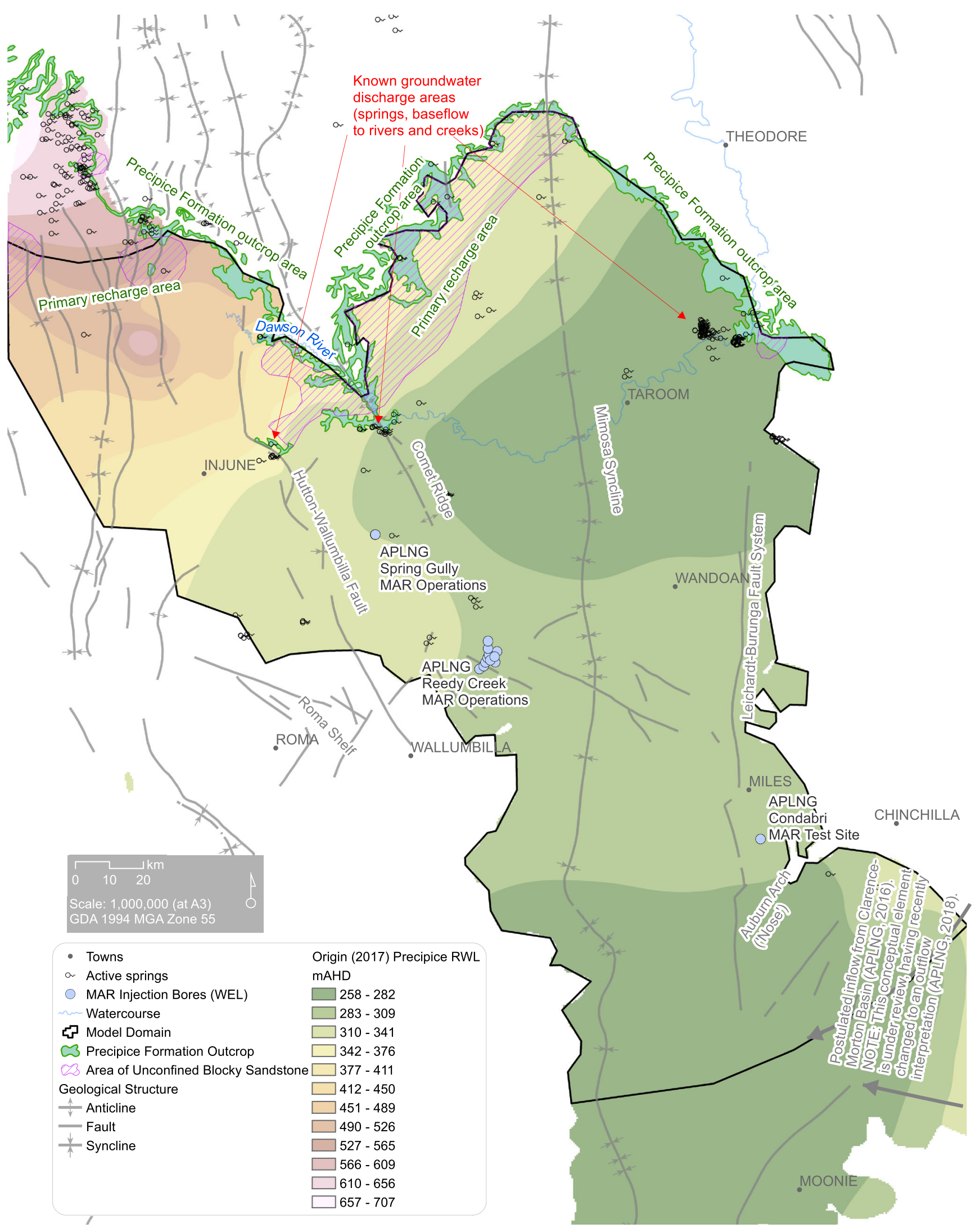

Fig. 5 Conceptual model elements and numerical model domain. RWL refers to rest water level in metres relative to the Australian Height Datum (m AHD) 


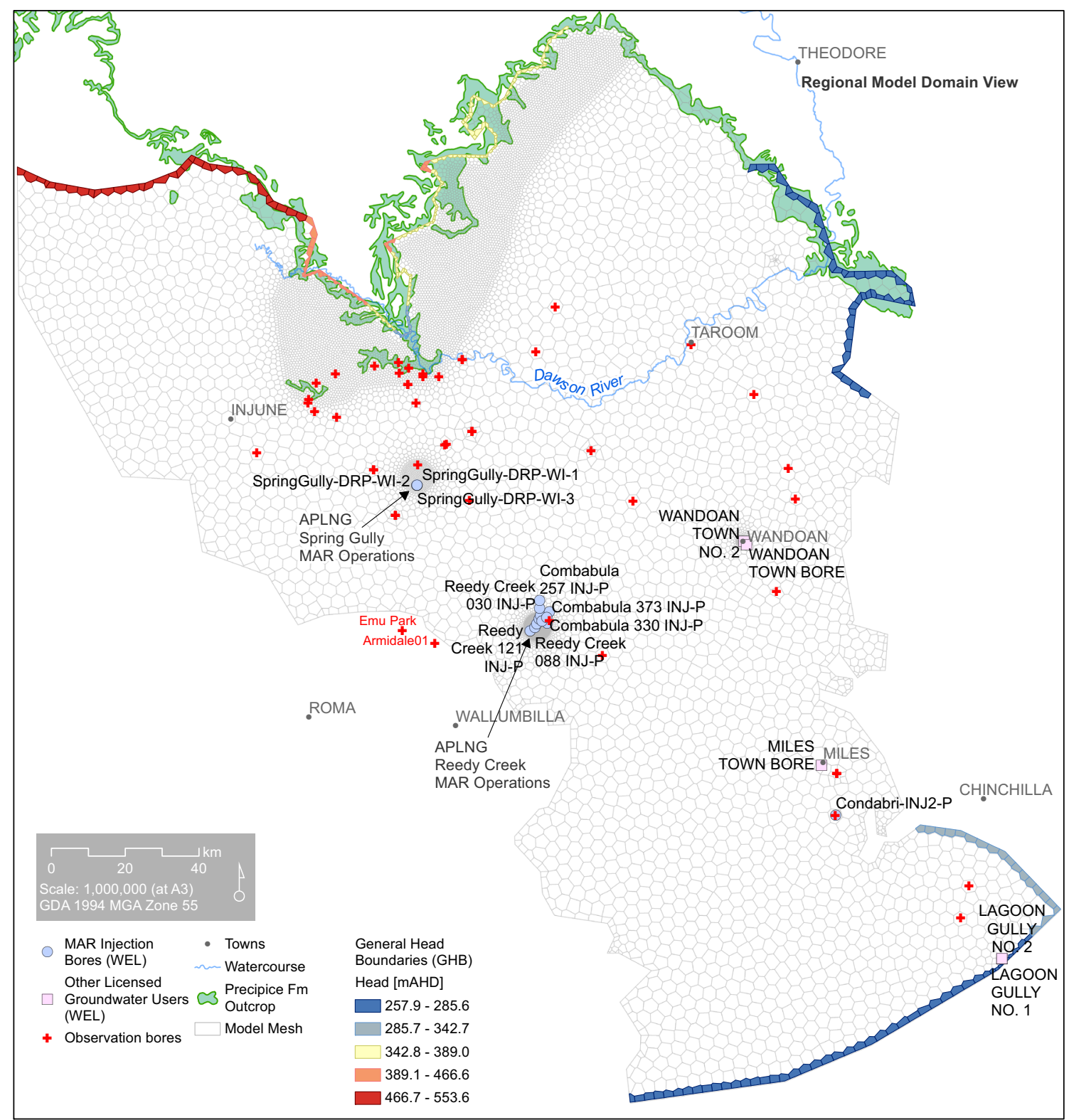

Fig. 6 Numerical model mesh with MAR injection, pumped and observation bore locations

the most recent observations of Precipice Sandstone groundwater pressures show a levelling off, which may be interpreted as being due to: (1) reduced injection rates, (2) the large change in storage where the Precipice Sandstone becomes unconfined, (3) to vertical leakage, or (4) a combination of these factors. In the south, groundwater pressure heads continue to rise (Origin Energy 2018).

\section{MAR inversion modelling method}

The recently revised geological interpretation concerning the areal extent of connected, high quartz content, permeable sandstone is tested using groundwater model inversion of the pressure observations of MAR injection. To invert the MAR observed pressure responses a simple three-layer groundwater model is developed, using Precipice Sandstone upper and lower surfaces from lithostratigraphic interpretations of Gonzalez et al. (2019) that define the aquifer thickness over the extent of Fig. 3b. The model layers correspond to the lower three units of the second lithostratigraphic scheme in Fig. 2: Lower Evergreen Formation, Precipice Sandstone and Moolayember Formation. The model is regionally extensive covering $37,800 \mathrm{~km}^{2}$, extending from the northern (unconfined) outcrop areas of the Precipice Sandstone to deeply confined areas around Chinchilla, representing the extent of observed pressure change, as shown in Figs. 5 and 6. The MODFLOW-USG (MF-USG) code (Panday et al. 2013) 
is used, with a Voronoi mesh that is locally refined around APLNG MAR injection bores, observation bores, and other key hydrogeological features of the model, significantly coarsening away from these features.

MAR injection, town water and industrial supply bores are included within the model using the MF-USG WEL boundary condition (Panday et al. 2013) with historical pumping or injection rates where available (see Fig. 6). MF-USG General Head Boundaries are specified along the northern outcrop areas, and southern model boundary to define the flow system with elevations set from groundwater contouring completed by Origin Energy and OGIA, as shown in Fig. 5. The elevation of northern constant head boundaries and layer elevations ensure the model represents a transition from unconfined to confined aquifer conditions close to outcrop of the Precipice Sandstone in the north. Observation data includes government, private landholder and CSG operator's bores; a total of 45 observation bore records are used in the inversion at locations shown on Fig. 6.

The model simulates a single steady-state stress period to provide initial heads, followed by 53 half-monthly transient stress periods, starting January 1st, 2015 and ending March 16th, 2017. The variable thickness and elevation of the Precipice Sandstone is represented by model Layer 2 with over and underlying Layers 1 and 3 having constant thickness of $20 \mathrm{~m}$. Layers 1 and 3 are included to permit water leaking vertically and being taken into storage by under and overlying aquitards, rather than being designed to accurately represent the geometry or properties of the overlying or underlying strata.

Inversion of the MAR injection observations is completed using PEST-HP (Doherty 2018) with spatiallyvarying pilot point parameters for hydraulic conductivity and specific storage within the Precipice Sandstone in model Layer 2, as shown in Fig. 7. A $10 \mathrm{~km}$ grid of pilot points throughout the model domain defines adjustable model parameters that are collectively used to interpolate (log-transformed) parameters to each MF-USG model node via the kriging function of PLPROC (Doherty 2016a). Ordinary kriging is used in the first instance, with no anisotropy, no nugget, a sill of $1 \mathrm{log}$ cycle, and a typical range of $45 \mathrm{~km}$ or a sufficiently larger distance to find at least four neighbouring points. Initial pilot point hydraulic properties and allowable ranges are shown in Table 1 . Ranges were primarily defined with reference to OGIA (2016c) and Origin (2018).

Regularisation is implemented using PEST-HP (Doherty 2018) to encourage the inversion process to prefer spatial parameter homogeneity over heterogeneity, to the extent that the available field data support such homogeneity. Initial regularisation weights for each pilot point are defined using covariance matrices constructed using PPCOV_SVA (Doherty 2016a) using the kriging variogram details described previously.
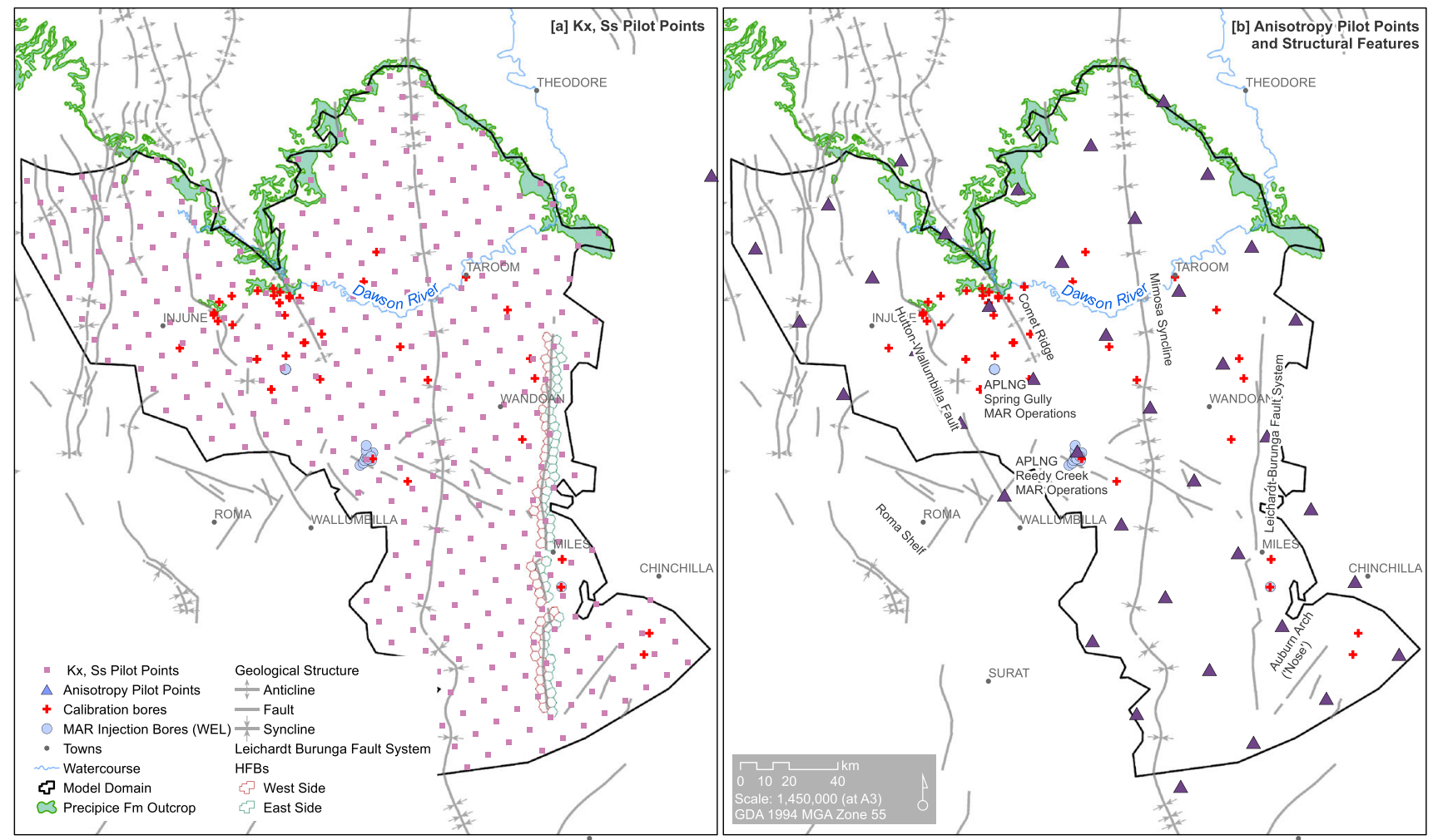

Fig. 7 a Pilot points and faults (HFBs) and b structural features 
Table 1 Summary of hydraulic property parameterisation

\begin{tabular}{|c|c|c|c|c|c|c|c|}
\hline Parameter & $\begin{array}{l}\text { Model } \\
\text { layer(s) }\end{array}$ & Hydrostratigraphic unit & Type & $\begin{array}{l}\text { Initial } \\
\text { value }\end{array}$ & $\begin{array}{l}\text { Minimum } \\
\text { value }\end{array}$ & $\begin{array}{l}\text { Maximum } \\
\text { value }\end{array}$ & Units \\
\hline \multirow[t]{2}{*}{$\begin{array}{l}\text { Horizontal hydraulic conductivity } \\
\qquad(\mathrm{Kx})\end{array}$} & 1,3 & Over- / under-burden & $\begin{array}{l}\text { Model-wide } \\
\text { zone }\end{array}$ & $1.0 \mathrm{E}-5$ & $1.0 \mathrm{E}-7$ & $1.0 \mathrm{E}-3$ & $\mathrm{~m} /$ day \\
\hline & 2 & $\begin{array}{l}\text { Precipice Sandstone } \\
\quad \text { (Blocky Sandstone) }\end{array}$ & Pilot points & $5.0 \mathrm{E}+0$ & $1.0 \mathrm{E}-6$ & $2.0 \mathrm{E}+2$ & $\mathrm{~m} /$ day \\
\hline $\begin{array}{l}\text { Vertical hydraulic conductivity factor } \\
\text { (of Kx) (Kzf) }\end{array}$ & $1,2,3$ & All & $\begin{array}{l}\text { Model-wide } \\
\text { zone }\end{array}$ & $1.0 \mathrm{E}-1$ & $1.0 \mathrm{E}-5$ & $1.0 \mathrm{E}+0$ & - \\
\hline \multirow[t]{2}{*}{ Specific storage } & 1,3 & Over-burden/under-burden & $\begin{array}{l}\text { Model-wide } \\
\text { zone }\end{array}$ & $1.0 \mathrm{E}-5$ & $1.0 \mathrm{E}-6$ & $9.0 \mathrm{E}-5$ & per m \\
\hline & 2 & $\begin{array}{l}\text { Precipice Sandstone } \\
\quad \text { (Blocky Sandstone) }\end{array}$ & Pilot points & $1.0 \mathrm{E}-6$ & 7.0E-8 & $1.0 \mathrm{E}-5$ & per $\mathrm{m}$ \\
\hline $\begin{array}{l}\text { Leichardt Burunga Fault System HFB } \\
\text { (northern, southern and central } \\
\text { sections) }\end{array}$ & $1,2,3$ & All & $\begin{array}{c}\text { Fault (HFB), } \\
3 \text { zones }\end{array}$ & $1.0 \mathrm{E}-5$ & $1.0 \mathrm{E}-8$ & $1.0 \mathrm{E}+1$ & $\begin{array}{l}\text { m/day (per m barrier } \\
\text { width; assumed } \\
10 \mathrm{~m} \text { ) }\end{array}$ \\
\hline Kriging anisotropy & 2 & $\begin{array}{l}\text { Precipice Sandstone } \\
\quad \text { (Blocky Sandstone) }\end{array}$ & Pilot points & $1.0 \mathrm{E}+0$ & $1.0 \mathrm{E}+0$ & $1.0 \mathrm{E}+2$ & - \\
\hline Kriging angle & 2 & $\begin{array}{l}\text { Precipice Sandstone } \\
\quad \text { (Blocky Sandstone) }\end{array}$ & Pilot points & 0 & -180 & 180 & Degrees from north \\
\hline
\end{tabular}

Other single parameters for each layer included in the inversion are vertical and horizontal hydraulic conductivity of layers 1 and 3 together with specific storage and specific yield in layer 1. Single parameters were adopted for parameters in layers 1 and 3 since no observations of pressure response were available for over- or under-lying formations.

The MF-USG Horizontal Flow Barrier (HFB) package (Panday et al. 2013) is used to simulate the postulated hydraulic barrier effect of the Leichardt-Burunga Fault System, a major north-south trending structure on the eastern side of the basin (see Fig. 5). The basis for this approach is the result of a discussion with Origin Energy staff and their observation of strong hydraulic barrier effects evident in responses to the short-term injection trial on the Condabri-INJ002 bore shown on Fig. 8 (R. Morris, RDM Hydro, personal communication, May 2018). Other known faults such as the HuttonWallumbilla Fault (Fig. 5), were not included as there is no clear evidence of them influencing the propagation of the MAR injection pressure signal.

Horizontal flow barrier nodes are shown on Fig. 7a, with flow between the eastern and western sides of the structure restricted by the prescribed hydraulic conductivity of the fault rock materials. The fault system is parameterised using three distinct zones, one for each of its northern, central and southern portions. The hydraulic conductivity of each of these zones is adjustable by the PEST inversion process.

Model inversion was repeated with varying interpolation schemes and parameters, both with and without kriging anisotropy. IDENTPAR, a PEST utility (Doherty 2016b) is used to assess parameter identifiability based on the available observation data. PEST-HP (Doherty 2018) and the PREDUNC7, RANDPAR and PNULPAR (Doherty 2016b) programs are used to produce mapping of calibrationconstrained hydraulic property uncertainty ranges.

Key calibration statistics indicate a reasonable degree of fit with a normalised root mean square error (nRMS) of $1.9 \%$, and of perhaps greater meaning, a mean absolute error of $0.43 \mathrm{~m}$ in water level change forecast. The nRMS is well within typically acceptable ranges (Barnett et al. 2012). Cumulative residuals show no significant bias, and more than $90 \%$ of modelled groundwater level changes are within $1 \mathrm{~m}$ of their observed counterparts. Model convergence is very good with a cumulative mass balance error of $<0.01 \%$. Hydrograph results of the calibration and inversion process for all wells are presented in Figs. S1-S45 of the electronic supplementary material (ESM).

\section{Results}

Figure 9 shows inverted estimates of hydraulic conductivity interpolated from the pilot points, together with maps of Precipice Sandstone thickness, transmissivity and conversion to intrinsic permeability (see text in the ESM). The plots show a range in hydraulic conductivity from 0.1 to $200 \mathrm{~m} /$ day and a transmissivity range from 10 to $10,000 \mathrm{~m}^{2} /$ day. Intrinsic permeability ranges from $100 \mathrm{mD}$ to $193 \mathrm{D}$. The highest transmissivity values are centred on the Spring Gully MAR injection site and in an area to the northwest of that site and bounded by the Hutton-Wallumbilla Fault. Through the remainder of the basin transmissivity values are typically in the range of $100-1,000 \mathrm{~m}^{2} /$ day, although lower values are present to the east of Reedy Creek and Spring Gully and in the southeast of the model. Broad-scale directional correlations between pilot 

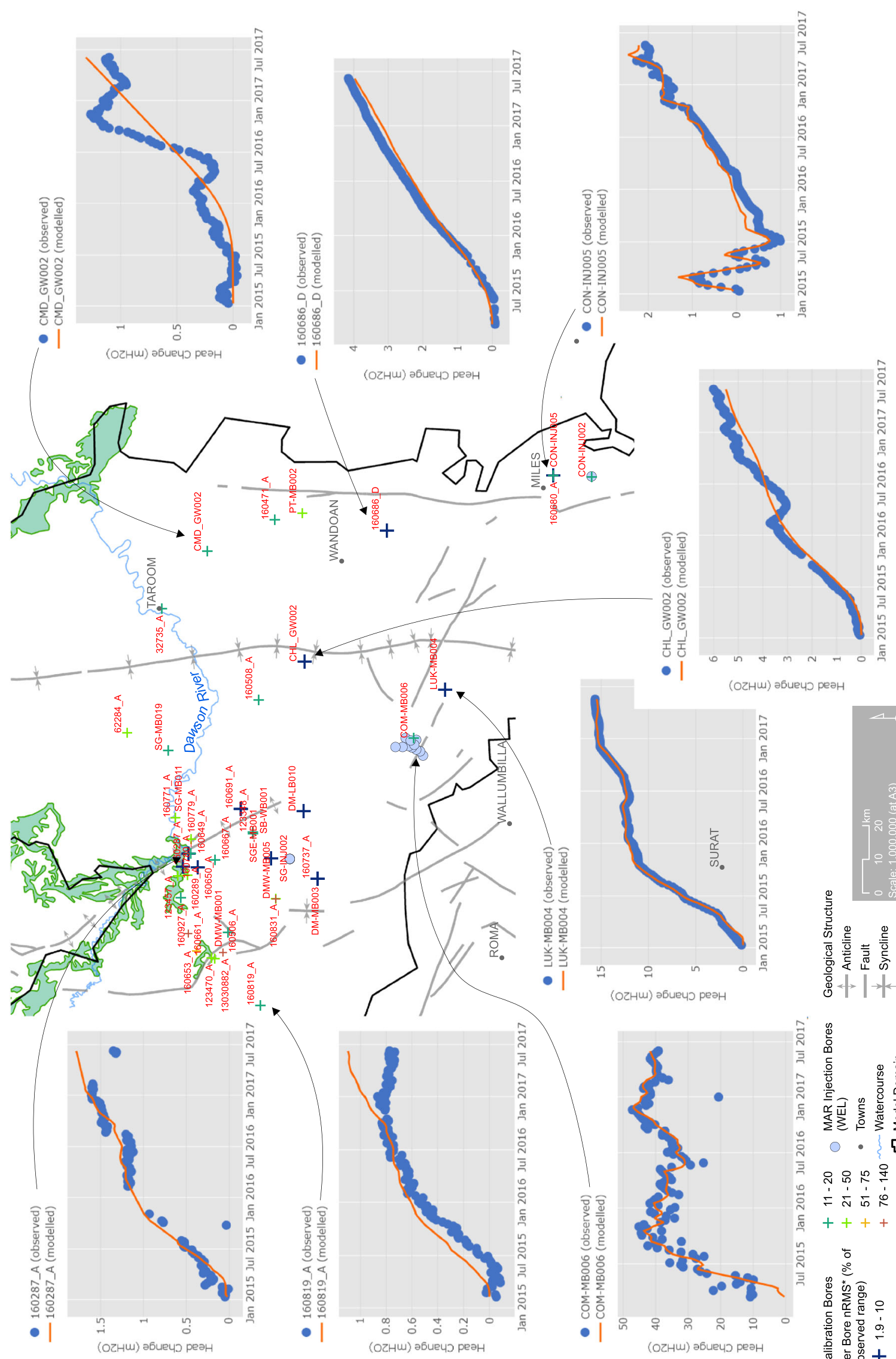

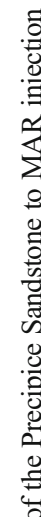

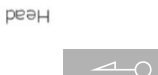


point parameters are evident in the developed permeability mapping, at least in some areas.

Small blue marks on the maps (Fig. 9) indicate the magnitude and direction of anisotropy in hydraulic conductivity. The model inversion indicates that kriging anisotropy is not required to simulate the observed pressure responses to MAR injection. Precipice Sandstone permeability appears isotropic at the scale of investigation, which is reflected in the blue marks appearing effectively as dots, rather than pointers. The minimum error variance model's maximum anisotropy ratio within the entire model domain is less than 2 (Fig. 9). Enough spatial variability and directional correlation (to achieve an acceptable level of inversion quality) was achieved prior to the introduction of kriging anisotropy into the inversion process; in some ways, the process of spatial regularisation may have achieved a similar end purpose as was intended through kriging anisotropy, and therefore rendered the kriging anisotropy redundant.

Maps of inverted specific storage and depth integrated storativity for the Precipice Sandstone are shown in Fig. 10. The specific storage distribution shows less spatial variability than permeability, with values in the range $1-2 \times 10^{-6} \mathrm{~m}^{-1}$ most common. These are consistent with plausible limits of specific storage values outlined by Rau et al. (2018).

Figure 11 presents the range of permeability (as hydraulic conductivity) estimated through the application of PEST and a calibration-constrained Monte-Carlo analysis; the Null Space Monte Carlo methods of PEST were not applied in this case because model run times were efficient enough to negate its need. It shows maps of the 5th, 50th and 95th percentile estimated hydraulic conductivity together with the uncertainty range which is defined as the ratio of the 95 th to 5 th percentile. Also, on these maps are blue dots or lines indicating the magnitude and direction of estimated anisotropy. For the 5th and 50th percentile maps, anisotropy is low, only becoming appreciable in the 95th percentile plot.

Plots of the identifiability of anisotropy, anisotropy angle, hydraulic conductivity and specific storage are presented in Fig. 12. These plots are generated using the IDENTPAR utility (Doherty 2016b) which enables estimates of the relative identifiability of all parameters optimised during inversion. Identifiability is a relative measure of the information content

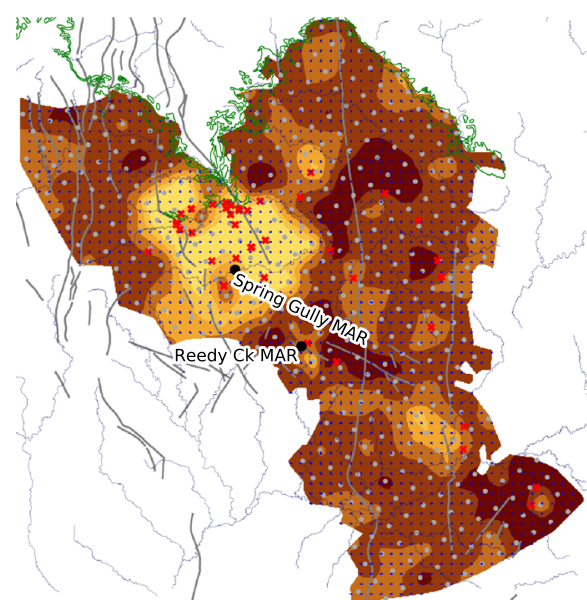

(a) Horizontal Hydraulic Conductivity (m/day)

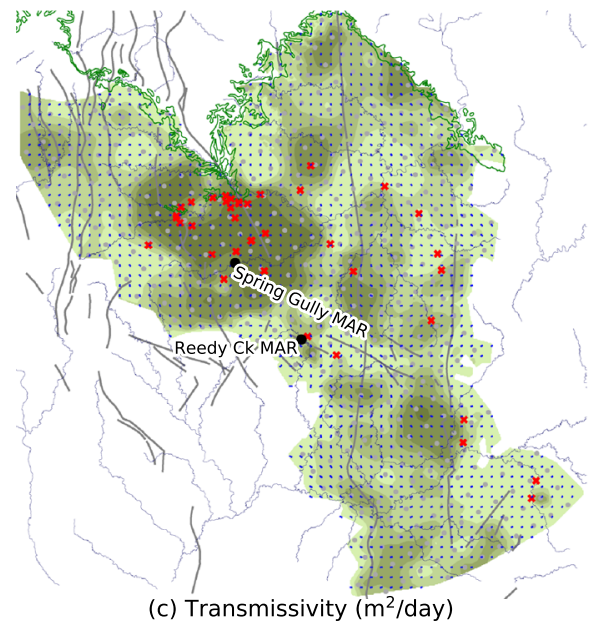

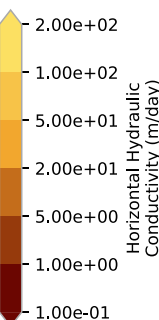

$1.00 \mathrm{e}-01$

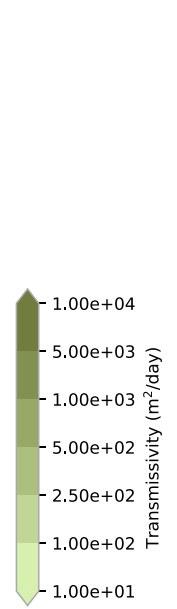

Fig. 9 a Hydraulic conductivity, b Precipice Sandstone thickness, $\mathbf{c}$ transmissivity, and $\mathbf{d}$ intrinsic permeability estimates from inversion
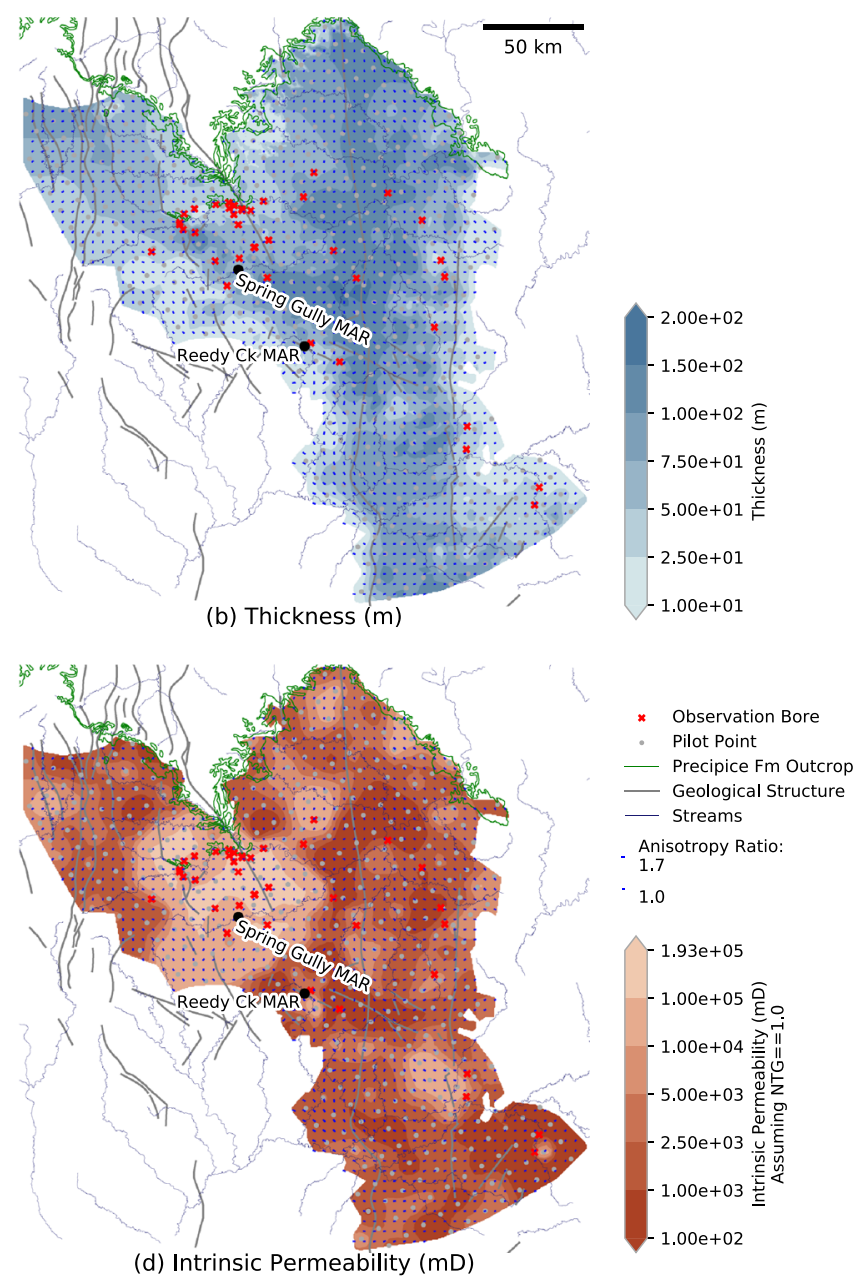


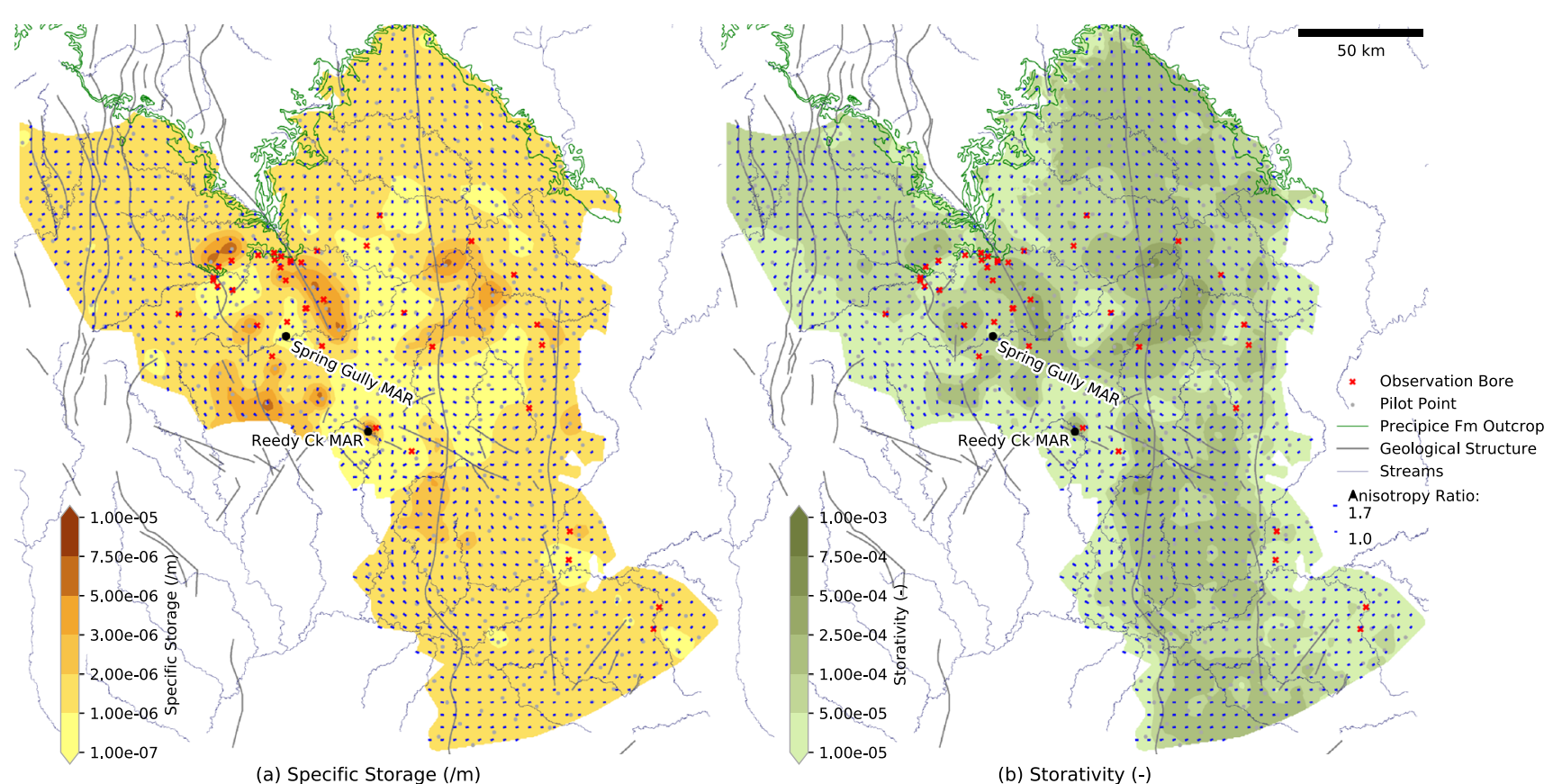

Fig. 10 Inversion estimated Precipice Sandstone: a specific storage, and b storativity

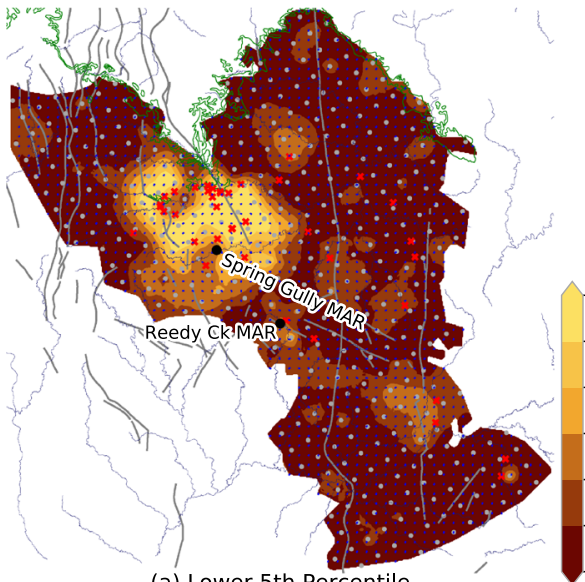

(a) Lower 5th Percentile

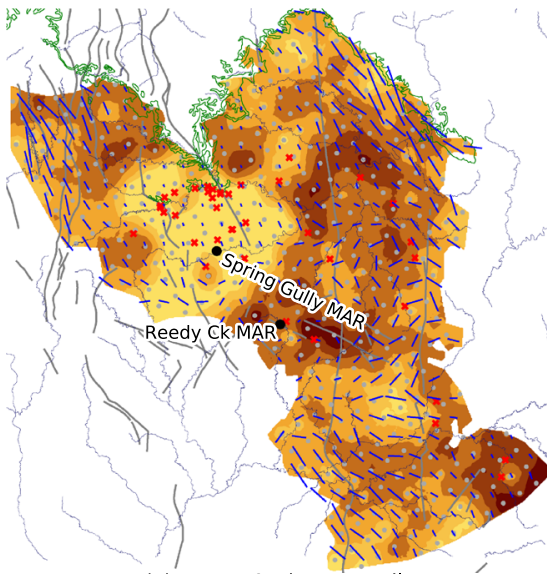

(c) Upper 95th Percentile

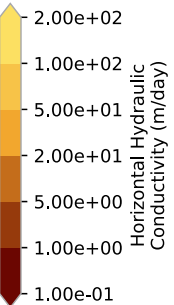

$\times$ Observation Bore Pilot Point

Precipice Fm Outcrop

- Geological Structure

— Streams

Anisotropy Ratio:

29.6
$-\quad 15.3$

- 1.0

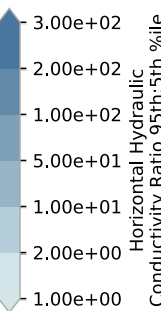

$-1.00 e+00$

Fig. 11 Uncertainty percentiles (a-c) and $\mathbf{d}$ uncertainty range in Precipice Sandstone hydraulic conductivity and anisotropy

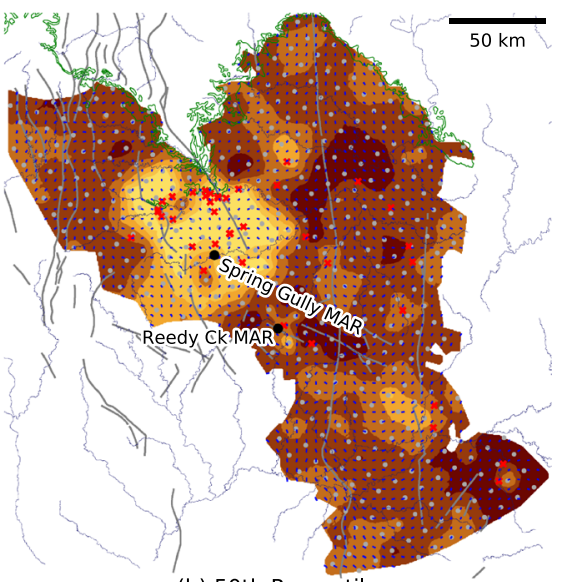

(b) 50th Percentile

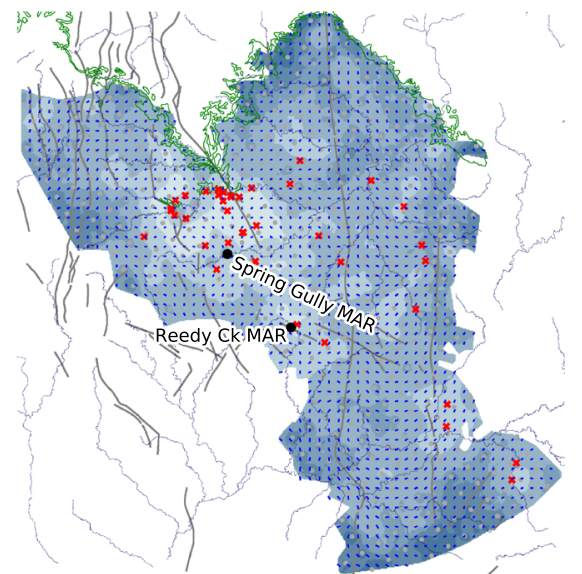

(d) Uncertainty Range 
of the inversion (observation) data set, with respect to constraining parameter values (a value of 1 indicates completely estimable parameters, and 0 a parameter that is inestimable). Figure 12 is useful in understanding the spatial coverage of observation data information content in the context of the MAR inversion process. As would be expected, the spatial identifiability distributions shown in Fig. 12 are correlated to the uncertainty ranges shown in Fig. 11, with more identifiable hydraulic conductivity and aquifer storage parameters around and between the Reedy Creek and Spring Gully MAR schemes.

Hydraulic conductivity and specific storage parameters at and in areas close to the MAR injection areas are more identifiable than are the kriging anisotropy parameters; conversely, in areas away from the MAR injection centres, the kriging anisotropy parameters generally become more identifiable than hydraulic conductivity and storage parameters. Specific storage identifiability is low beyond the vicinity of the MAR injection areas, which may indicate that the duration of the MAR injection data, at 30 months, is insufficient to explore storage at the basin-scale.
Analysis of optimised inversion parameters shows that the information content of many pilot point parameters is shared between those pilot points (i.e. they are correlated and nonunique); these are in areas distal to the major MAR injection centres. Aquifer storage parameters are significantly less identifiable than are hydraulic conductivity parameters. Of the zone-based parameters, the specific yield of the unconfined Precipice Sandstone in the north is the single most identifiable. All other zone-based parameters are relatively less identifiable, and generally less tightly constrained. The exceptions to this are horizontal hydraulic conductivity of the over- and under-burden ('kx1_3') and the vertical hydraulic conductivity factor of all model layers ('kzf'): these probably control the model's mimicry of storage contributions from overlying and underlying strata that are not modelled in detail.

Model parameters representing Leichardt-Burunga Fault system hydraulic conductivity ('hfbnorth', 'hfbcentral' and 'hfbsouth') are some of the least identifiable, with the northern-most section the most identifiable of the three. This could be due to the relatively short duration of the Condabri

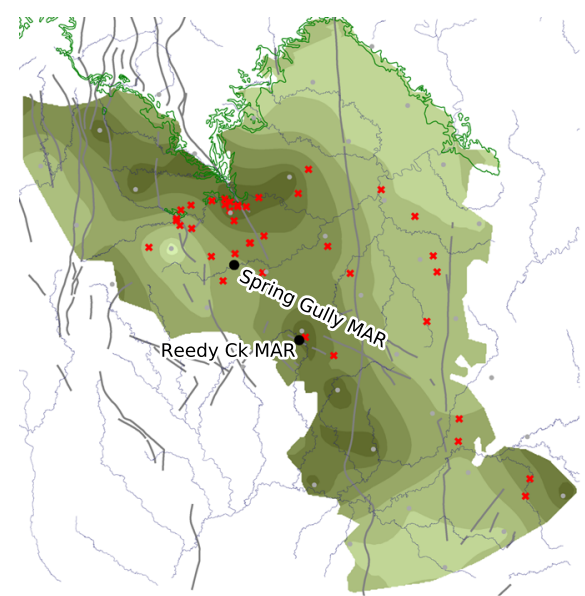

(a) Kriging Anisotropy

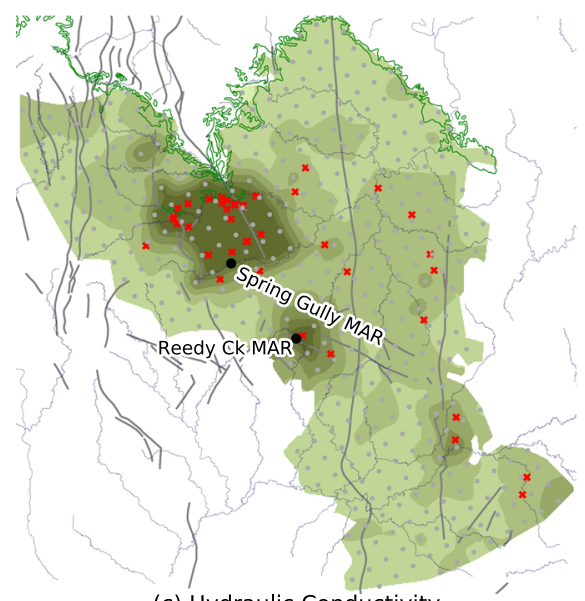

(c) Hydraulic Conductivity

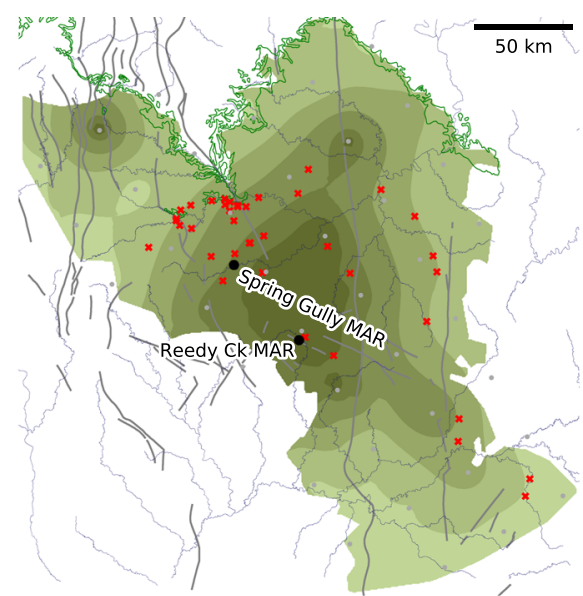

(b) Kriging Angle

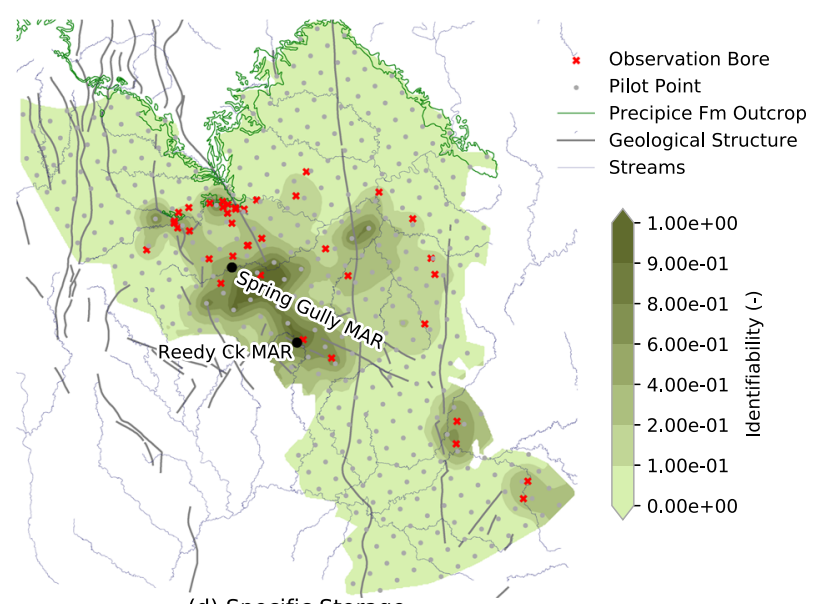

(d) Specific Storage

Fig. 12 Precipice Sandstone parameter identifiability: a kriging anisotropy, $\mathbf{b}$ kriging angle, $\mathbf{c}$ hydraulic conductivity, and $\mathbf{d}$ specific storage 
push-pull test included in the MAR simulation, and the limited number of bores affected by that test.

Hydrographs in the ESM include pressure data for two observation bores (Emu Park and Armidale01) on the Roma Shelf, around $35 \mathrm{~km}$ southwest of Reedy Creek that lie outside the extent of the Precipice Sandstone mapped by sequence stratigraphy. Bore logs classified them as being completed within the Precipice Sandstone, but they show no pressure responses to MAR injection, despite their proximity to Reedy Creek. This null response supports the reduced extent of the Precipice Sandstone presented in Fig. 3b and indicates that these bores are likely completed in sandstones within the Evergreen Formation.

\section{Discussion}

Model inverted permeability distributions of the Precipice Sandstone show significant spatial variability, with an area of very high isotropic hydraulic conductivity around the Spring Gully MAR injection scheme (20$200 \mathrm{~m} /$ day). This result is supported by observations of Origin Energy staff who report a very porous competent sandstone, with large aperture fractures (R. Morris, RDM Hydro, personal communication, May 2018). The magnitude of the hydraulic conductivities, reaching into the hundreds of $\mathrm{m} / \mathrm{day}$, is unusual for a consolidated sandstone but is consistent with fracture flow enhancing porous media permeability.

A possible cause of the fracturing may be curvature of the Precipice Sandstone over a northwest--southeast trending anticline known as the Comet Ridge (Fig. 5). A concept of the Precipice Sandstone being fractured above the Comet Ridge is supported by mapping of geomechanical stresses of the Surat Basin in studies reported by Flottman et al. (2013) and Tavener et al. (2017). These show no coherent trend in maximum principal stress in the area of high permeability around Spring Gully, as may be present in an extensional setting. Taken together, the core observations, inversion results and stress information indicate that around Spring Gully a dual porosity groundwater flow regime exists. This result differs from that of Suckow et al. (2018) who found no evidence of a Precipice Sandstone dual porosity system in isotope tracers. This has implications for the mixing of MAR waters with natural Precipice Sandstone groundwater and on estimates of flow velocities and residence times.

The area of relatively high hydraulic conductivity around the Reedy Creek MAR injection scheme $(5-50 \mathrm{~m} /$ day), is bounded by linear-shaped areas of relatively low values $(0.1-1 \mathrm{~m} /$ day $)$ to the northwest, east and southeast, extending linearly from Reedy Creek toward Miles and Condabri. The spatial geometry of this higher hydraulic conductivity zone and bounding lower hydraulic conductivity areas broadly follow the maximum stress orientations recorded in this area (Flottman et al. 2013; Tavener et al. 2017) and local structural features (see Fig. 5). This suggests stress and structure are likely controls on aquifer permeability.

The relatively localised very high permeability zone at Spring Gully, and a lesser degree Reedy Creek, may have implications elsewhere in the GAB where sandstones have been subject to extensional stress regimes. The magnitude of fracturing and associated permeability is distinct to smaller and local scale fracturing that often occur in sandstones in the GAB and elsewhere, for example in Triassic sandstone aquifers in the UK (Tellam and Barker 2006). This smaller scale fracturing is observed in Precipice Sandstone, for example in the Chinchilla 4 well core (Fig. 3b), with both high and low core permeabilities reported (Pearce et al. 2015, 2019).

In the inversion, another structure close to the MAR injection sites, the Hutton-Wallumbilla Fault (see Fig. 5), appears to have little influence on pressure propagation from MAR injection. This fault was not represented explicitly using flow barriers but inverted hydraulic properties in the vicinity of the fault were expected to reflect any impedance to flow or pressure. More recent work directly considering the influence of the fault shows it to exert significant local control on Precipice Sandstone groundwater flow, and discharge to Hutton Creek to the northwest of Spring Gully (D. Gornall, Santos, personal communication, Jan 2019). Potential explanations for why the inversion is not influenced by the Hutton-Wallumbilla Fault are insufficient observation data density and the fault's orientation and offset north-westward away from Spring Gully. This may permit propagation of pressure increases due to MAR parallel to, and on either side of the fault, whereas the fault impedes regional flow from further northwest toward Hutton Creek.

Inversion results suggest the Precipice Sandstone to have broadly isotropic permeability. This is consistent with core descriptions of very coarse grained to pebbly sandstone indicative of a high energy depositional environment and the interpretation of Wang et al. (2019) of a 'thick braided distributary channel facies'. The Precipice Sandstone has been modelled previously by OGIA in their 2016 UWIR model. The MAR inversion has estimated hydraulic conductivity values $1-2$ orders of magnitude higher than the OGIA 2016 representation, demonstrating clearly the data value of the MAR injection signal. Further, the reduced lateral extent of the Precipice Sandstone postulated by La Croix et al. (2019) and Wang et al. (2019) is supported by hydrogeological observations and the groundwater modelling inversion. This is especially true of the observations at Armidale 1, where no response is observed to injection at Reedy Creek some $35 \mathrm{~km}$ away (see hydrographs in Figs. 46 and 47 of ESM).

The water resources of the Precipice Sandstone are managed by the Queensland Department of Natural Resources and Mines (DNRME) via their Great Artesian Basin and Other 
Regional Aquifers Plan (Queensland Government 2017). The plan sets out methods to protect springs and existing groundwater wells from new licenses based on tables calculated using confined aquifer analytical solutions to estimate impacts from new licences. The plan uses hydraulic parameters based on data for specific aquifers and basins. For the Precipice Sandstone DNRME use a transmissivity of $50 \mathrm{~m}^{2} /$ day and a storage coefficient of $5 \times 10^{-4}$. Taking an average sandstone thickness of $80 \mathrm{~m}$, this corresponds to a depth averaged hydraulic conductivity of $0.6 \mathrm{~m} /$ day. This value is nearly an order of magnitude lower than the geometric mean of MAR inversion, $4.3 \mathrm{~m} /$ day. The reduced Precipice Sandstone extent and reinterpretation of the Evergreen and Precipice sequence stratigraphy supported by observations and modelling and the higher overall permeability of the Precipice Sandstone both have implications for the regulation of water resources in the lower formations of the Surat Basin.

\section{Conclusions}

The observed pressure changes due to MAR injection demonstrates a high degree of connectivity within the Precipice Sandstone across distances of more than $100 \mathrm{~km}$, including across the Mimosa Syncline where the depth of burial of the Precipice Sandstone is in excess of 1,500 m. The rapid propagation of the signal is indicative of elevated aquifer diffusivity (i.e. high permeability and low specific storage).

This report demonstrates the application of MAR pressure change observations to inform geological and hydrogeological understanding of a major GAB aquifer. Through modelling and inversion, recent geological interpretations by Wang et al. (2019) and La Croix et al. (2019) of a more limited spatial extent for the basal unit of the Precipice Sandstone are supported. Model inversion has revealed the magnitudes and spatial variability of aquifer hydraulic parameters. Results show very high hydraulic conductivity around the Spring Gully MAR site, and overall higher hydraulic conductivity than previous estimates. Precipice Sandstone permeability appears to be broadly isotropic, which is consistent with a high energy depositional environment and a braided distributary channel facies. A likely link has been established between structure, an extensional stress regime across Comet Ridge, fracturing in the Precipice Sandstone and the very high permeability dual porosity system at Spring Gully. This may have implications elsewhere in the $\mathrm{GAB}$ where sandstones have been subject to extensional stress regimes.

This study demonstrates the effective use of MAR observations as a long-term aquifer pressure test, akin to a pumping test. The inversion is based on observed pressure (head) changes, like a pumping test analysis, rather than considering absolute groundwater head. Whilst this enabled rapid model development and inversion, it also means that the groundwater model is not calibrated in terms of regional groundwater heads and cannot be applied to explore the flow rates through the Precipice Sandstone from recharge sources to points of discharge. Further work is required to incorporate the results of the Precipice Sandstone inversion into a regional model to explore Surat Basin flow pathways, connectivity between formations, the evolution of hydrochemistry and the rates of recharge, through-flow and discharge to further inform water resource management.

The development of understanding of the Precipice Sandstone as an aquifer in this study has used and integrated the substantial data acquired from Surat Basin oil and gas development, including CSG, together with hydrogeological data, techniques and modelling methods. The detailed integration of datasets and pressure change observations may be applicable in other locations where groundwater and petroleum development target the same formations and areas. The application of the PEST suite of tools to invert parameter fields, and assess the accuracy of those inversions, is particularly suited to situations where clear new signals such as those from MAR, may propagate through aquifers. Such stresses on natural systems present valuable opportunities to develop hydrogeological understanding, where adequate and suitable monitoring is present.

Acknowledgements We acknowledge and thank APLNG, Santos and Shell/QGC for provision of observation data, the assistance of Alex Wolhuter in preparation of some figures, discussion with Carlos Miraldo Ordens Castelo Branco, and insightful, constructive comments from Brian Smerdon and Hugh Middlemis that substantially improved the manuscript.

Funding information This study was undertaken as part of the Surat Deep Aquifer Appraisal Project (UQ-SDAAP), which was funded by: the Australian Government through the Carbon Capture and Storage Research Development and Demonstration (CCS RD\&D) programme; by Coal 21; and The University of Queensland.

Open Access This article is licensed under a Creative Commons Attribution 4.0 International License, which permits use, sharing, adaptation, distribution and reproduction in any medium or format, as long as you give appropriate credit to the original author(s) and the source, provide a link to the Creative Commons licence, and indicate if changes were made. The images or other third party material in this article are included in the article's Creative Commons licence, unless indicated otherwise in a credit line to the material. If material is not included in the article's Creative Commons licence and your intended use is not permitted by statutory regulation or exceeds the permitted use, you will need to obtain permission directly from the copyright holder. To view a copy of this licence, visit http://creativecommons.org/licenses/by/4.0/.

\section{References}

Akers HF (2010) A complex mosaic: groundwater, "the big spill" and the wool industry in pre-1960 Queensland. Queensland Hist J 21:196-212 
Allinson WG, Nguyen DN, Bradshaw J (2003) The economics of geological storage of $\mathrm{CO}_{2}$ in Australia. The APPEA J 43:623-636

Barnett B, Townley LR, Post V, Evans RE, Hunt RJ, Peeters L, Richardson S, Werner AD, Knapton A, Boronkay A (2012) Australian groundwater modelling guidelines. National Water Commission, Canberra

Bianchi V, Zhou F, Pistellato D, Martin M, Boccardo S, Esterle J (2018) Mapping a coastal transition in braided systems: an example from the Precipice Sandstone, Surat Basin. Aust J Earth Sci 65:483-502. https://doi.org/10.1080/08120099.2018.1455156

Bradshaw BE, Spencer LK, Lahtinen A-L, Khider K, Ryan DJ, Colwell JB, Chirinos A, Bradshaw J, Draper JJ, Hodgkinson J (2011) An assessment of Queensland's $\mathrm{CO}_{2}$ geological storage prospectivity: the Queensland $\mathrm{CO}_{2}$ geological storage atlas. Energy Procedia 4: 4583-4590

Bradshaw J, Bradshaw BE, Allinson G, Rigg AJ, Nguyen V, Spencer L (2002) The potential for geological sequestration of $\mathrm{CO}_{2}$ in Australia: preliminary findings and implications for new gas field development. The APPEA J 42:25-46

Cosgrove JL, Mogg WG (1985) Recent exploration and hydrocarbon potential of the Roma Shelf, Queensland. Aust Petrol Explor Assoc J 25:216-234

Doherty J (2018) PEST: model-independent parameter estimation and uncertainty analysis - user manual. Watermark, Brisbane, Australia

Doherty J (2016a) PLPROC: a parameter list processor. Watermark, Brisbane, Australia

Doherty JE (2016b) Model-independent parameter estimation user manual part II: PEST utility support software. Watermark, Brisbane, Australia, $226 \mathrm{pp}$

EHP (2012) Coal seam gas water management policy. Dept. of Environment and Heritage Protection, Queensland Gov., Brisbane, Australia

Exon NF (1976) Geology of the Surat Basin in Queensland. Bureau of Mineral Resources, Geology and Geophysics, Canberra, Australia

Flottman T, Brooke-Barnett S, Trubshaw R, Naidu S-K, Kirk-Burnnand E, Paul P, Busetti S, Hennings P (2013) Influence of in situ stresses on fracture stimulation in the Surat Basin, Southeast Queensland. In: SPE Unconventional Resources Conference and Exhibition-Asia Pacific. Society of Petroleum Engineers, Richardson, TX

Gray ARG (1968) Stratigraphic drilling the Surat and Bowen basins, 1965-1966. Queensland Geological Survey

Gonzalez S, Harfoush A, La Croix A, Underschultz J, Garnett A (2019) Regional static model, the University of Queensland Surat Deep Aquifer Appraisal Project: supplementary detailed report. The University of Queensland, Brisbane, Australia

Green PM, Hoffmann KL, Brain TJ, Gray ARG (1997) The Surat and Bowen basins, south-east Queensland. Queensland Department of Mines and Energy, Brisbane, Australia

Grigorescu M (2011) Mineralogy of the north-eastern Bowen Basin and north-eastern Surat basin, Queensland. Queensland Geological Record 2, Queensland Gov., Brisbane, Australia

Hitchon B, Hays J (1971) Hydrodynamics and hydrocarbon occurrences, Surat Basin, Queensland, Australia. Water Resour Res 7:658-676. https://doi.org/10.1029/WR007i003p00658

Julie K. Pearce, Dirk M. Kirste, Grant K.W. Dawson, Susan M. Farquhar, Dean Biddle, Suzanne D. Golding, Victor Rudolph, (2015) SO 2 impurity impacts onexperimental and simulated $\mathrm{CO} 2$-water-reservoir rock reactions at carbon storage conditions. Chemical Geology 399:65-86

Hodgkinson J, Grigorescu M (2013) Background research for selection of potential geostorage targets: case studies from the Surat Basin, Queensland. Aust J Earth Sci 60:71-89

Keir G, Bulovic N, Mcintyre N, Callow I, Herbert C, Reading L, Costa F, Roux E (2017) Characterisation of current groundwater uses in the Surat and Bowen basins. The University of Queensland, Brisbane, Australia
Keir G, Bulovic N, Mcintyre N (2019) Stochastic modeling of groundwater extractions over a data-sparse region of Australia. Ground Water 57:97-109. https://doi.org/10.1111/gwat.12658

La Croix AD, Wang J, He J, Hannaford C, Bianchi V, Esterle JS, Underschultz JR (2019) Widespread nearshore and shallow marine deposition within the Lower Jurassic Precipice Sandstone and Evergreen Formation in the Surat Basin, Australia. Mar Petrol Geol 109. https://doi.org/10.1016/j.marpetgeo.2019.06.048

Martin KR (1980) Deposition of the Precipice Sandstone and the evolution of the Surat Basin in the Early Jurassic. APEA J 21:16-23

Martin MA, Wakefield M, Bianchi V, Esterle J, Zhou F (2018) Evidence for marine influence in the Lower Jurassic Precipice Sandstone, Surat Basin, eastern Australia. Aust J Earth Sci 65:75-91. https:// doi.org/10.1080/08120099.2018.1402821

Mollan RG, Forbes VR, Jensen AR, Exon NF, Gregory CM (1972) Geology of the Eddystone, Taroom and western part of the Munduberra Sheet areas, Queensland. Bureau of Mineral Resources, Geology and Geophysics, Australia, Canberra

OGIA (2016a) Hydrogeological conceptualisation report for the Surat Cumulative Management Area. Office for Groundwater Impact Assessment, Brisbane, Australia

OGIA (2016b) Underground water impact report for the Surat Cumulative Management Area. Department of Natural Resources and Mines, Office of Groundwater Impact Assessment, Brisbane, Australia

OGIA (2016c) Groundwater modelling report for the Surat Cumulative Management Area. Department of Natural Resources and Mines, Office of Groundwater Impact Assessment, Brisbane, Australia

Origin Energy (2018) 2017-2018 groundwater assessment report. Origin Energy, Sydney

O'Sullivan T, McGarry A.M. DJ, Kamenar A, Brown RS (1991) The discovery and development of Moonie; Australia's first commercial oilfield. The APPEA J 31:1-12

Panday S, Langevin CD, Niswonger RG, Ibaraki M, Hughes JD (2013) MODFLOW-USG version 1: an unstructured grid version of MODFLOW for simulating groundwater flow and tightly coupled processes using a control volume finite-difference formulation. US Geol Surv Tech Methods 6-A45

Pearce JK, Dawson GKW, Golab A, Knuefing L, Sommacal S, Rudolph $\mathrm{V}$, Golding SD (2019) A combined geochemical and $\mu \mathrm{CT}$ study on the $\mathrm{CO}_{2}$ reactivity of Surat Basin reservoir and cap-rock cores: porosity changes, mineral dissolution and fines migration. Int $\mathrm{J}$ Greenhouse Gas Control 80:10-24

Queensland Government (2017) Water plan: Great Artesian Basin and other regional aquifers. Queensland Gov. Brisbane, Australia

Queensland Government (2018) Petroleum and gas production and reserve statistics. In: Petroleum and gas production and reserve statistics: data. https://data.qld.gov.au/dataset/petroleum-gas-productionand-reserve-statistics. Accessed 12 Feb 2019

Ransley T, Somerville P, Tan KP, Feitz A, Cook S, Yates G, Schoning G, Bell J, Caruana L, Sundaram B, Wallace L (2015) Groundwater hydrochemical characterisation of the Surat region and Laura Basin, Queensland. Final technical report for the National Collaboration Framework Hydrochemical Characterisation Project, Geoscience Australia, Canberra

Rau GC, Acworth RI, Halloran LJS, Timms WA, Cuthbert MO (2018) Quantifying compressible groundwater storage by combining cross-hole seismic surveys and head response to atmospheric tides. J Geophys Res Earth Surf. http://agupubs. onlinelibrary.wiley.com/doi/abs/10.1029/2018JF004660. Accessed 29 Aug 2019

S.M. Rigby, A J. Kantsler, (1987) MURILLA CREEK - AN UNTESTED STRATIGRAPHIC PLAY IN THE SURAT BASIN. The APPEA Journal 27 (1):230

Sell BH, Brown LN, Groves RD (1972) Basal Jurassic sands of the Roma area. Queensland Gov Min J 73:309-321 
Smerdon B, Ransley T (2012) Hydrostratigraphy, hydrogeology and system conceptualisation of the Great Artesian Basin. A technical report to the Australian Government from the CSIRO Great Artesian Basin Water Resource Assessment. https://doi.org/10.4225/08/ 584c457b1676f

Suckow A, Raiber M, Deslandes A, Gerber C (2018) Constraining conceptual groundwater models for the Hutton and precipice aquifers in the Surat Basin through tracer data. Final report, CSIRO, Canberra

Tavener E, Flottmann T, Brooke-Barnett S (2017) In situ stress distribution and mechanical stratigraphy in the Bowen and Surat basins, Queensland, Australia. Geol Soc London Spec Publ 458:31-47

Tellam JH, Barker RD (2006) Towards prediction of saturated-zone pollutant movement in groundwaters in fractured permeable-matrix aquifers: the case of the UK Permo-Triassic sandstones. Geol Soc London Spec Publ 263:1-48. https://doi.org/10.1144/GSL.SP.2006. 263.01.01
Towler B, Firouzi M, Underschultz J, Rifkin W, Garnett A, Schultz H, Esterle J, Tyson S, Witt K (2016) An overview of the coal seam gas developments in Queensland. J Nat Gas Sc Eng 31:249-271. https:// doi.org/10.1016/j.jngse.2016.02.040

Underschultz JR, Pasini P, Grigorescu M, de Souza TL (2016) Assessing aquitard hydraulic performance from hydrocarbon migration indicators: Surat and Bowen basins, Australia. Mar Pet Geol 78:712-727. https://doi.org/10.1016/j.marpetgeo.2016.09.025

Vogel H (1921) Das Temperaturabhängigkeitsgesetz der Viskosität von Flüssigkeiten [The temperature dependence law of the viscosity of liquids]. Phys Z 22:645

Wang J, La Croix AD, Gonzalez S, He J, Underschultz JR (2019) Sequence stratigraphic analysis of the Lower Jurassic Precipice and Evergreen formations in the Surat Basin, Australia: implications for the architecture of reservoirs and seals for $\mathrm{CO}_{2}$ storage. Mar Pet Geol 102:829-843. https://doi.org/10.1016/j.marpetgeo.2019.01. 038 